\title{
Contactin-Associated Protein-Like 2
}

National Cancer Institute

\section{Source}

National Cancer Institute. Contactin-Associated Protein-Like 2. NCI Thesaurus. Code C73463.

Contactin-associated protein-like 2 (1331 aa, $\sim 148 \mathrm{kDa}$ ) is encoded by the human CNTNAP2 gene. This protein may play a role in the structural organization of axons. 